\title{
First Case of Canine Infection with Hepatozoon canis (Apicomplexa: Haemogregarinidae) in the Republic of Korea
}

\author{
Seung-Joo Kwon', Yoon-Hee Kim², Hyun-Hee Oh³, Ul-Soo Choi',** \\ 'College of Veterinary Medicine, Chonbuk National University, Iksan 54596, Korea; ²Western Animal Medical Center, Seoul 04103, Korea; \\ ${ }^{3}$ Kwangjin Animal Medical Center, Seoul 04975, Korea
}

\begin{abstract}
This report describes a dog infected with Hepatozoon canis, the first canine infection in the Republic of Korea. A 2-year-old intact male Maltese dog presented with anorexia and depression. Physical examinations revealed mild dehydration and hyperthermia $\left(39.8^{\circ} \mathrm{C}\right)$, and blood analysis showed pancytopenia. Diff-Quik staining of blood smear specimens showed the presence of ellipsoidal shaped structures (gamonts of $H$. canis) within a small number of neutrophils. Real-time PCR analysis using whole blood confirmed infection by $H$. canis. The clinical condition of the dog improved after symptomatic treatment and administration of doxycycline. Although a molecular epidemiologic survey in Korea showed $H$. canis infection of dogs, to our knowledge this is the first report of a dog infection in Korea molecularly shown to be $H$. canis.
\end{abstract}

Key words: Hepatozoon canis, hepatozoonosis, dog, Korea

\section{INTRODUCTION}

Hepatozoonosis is an arthropod-borne infection caused by Hepatozoon species (Apicomplexa: Haemogregarinidae) [1,2]. Hepatozoon species are transmitted by hematophagous invertebrate definitive hosts such as ticks, mites, mosquitoes, fleas, lice, sandflies, tsetse flies, and reduviid bugs [3,4]. Unlike many arthropod-borne pathogens which are transmitted via the salivary glands, Hepatozoon infection is established when an intermediate vertebrate host (mammal, amphibian, reptile, and bird) ingests the infected definitive host [1]. After ingestion, sporozoites penetrate the intestinal wall and reach the hemolymphatic target organs (liver, spleen, and bone marrow) either hematogenously or via the lymph. Merogony occurs in these organs, and the resulting meronts contain merozoites that penetrate neutrophils and develop into gamonts that appear in the peripheral blood. The Hepatozoon life cycle is completed when a vector ingests the infected blood $[3,5]$.

\footnotetext{
- Received 4 April 2016, revised 24 October 2016, accepted 11 November 2016.

*Corresponding author (uschoi@jbnu.ac.kr)

(C) 2017, Korean Society for Parasitology and Tropical Medicine

This is an Open Access article distributed under the terms of the Creative Commons Attribution Non-Commercial License (http://creativecommons.org/licenses/by-nc/4.0) which permits unrestricted non-commercial use, distribution, and reproduction in any medium, provided the original work is properly cited.
}

Only 2 species of hepatozoa, Hepatozoon canis and Hepatozoon americanum, have been known to infect dogs. The former occurs worldwide $[1,5]$, whereas the latter occurs only in the southeast part of the United States $[6,7]$. There have been 2 reports on Hepatozoon infection in Korea. The first was a molecular survey of $H$. canis infection in dogs [8], and the second was the finding of Hepatozoon felis infection in a leopard cat [9]. The clinical signs associated with $H$. canis infection vary from negligible (asymptomatic) to severe and fatal disease with anemia, fever, lethargy, cachexia, and weight loss $[2,10]$. Most cases of $H$. americanum infection have severe clinical signs [2].

The standard diagnosis of Hepatozoon infection is by microscopic detection of intracellular ellipsoidal-shaped gamonts within neutrophils in peripheral blood smears and "wheelspoke" meronts or monozoic tissue cysts in histopathologic specimens [11]. More recent diagnostic techniques, such as an enzyme-linked immunosorbent assay, an indirect fluorescent antibody test, and the polymerase chain reaction (PCR), can also detect Hepatozoon infection [12,13].

This report describes the first dog molecularly diagnosed with $H$. canis infection in Korea and provides an overview of this case. 
Table 1. Hematological findings of the present case

\begin{tabular}{|c|c|c|c|c|c|c|}
\hline Analyte & Normal Range & Units & Day 1 & Day 2 & Day 2 & Day 3 \\
\hline WBC & $6.0-17.0$ & $\times 10^{3} / \mu \mathrm{l}$ & 4.1 & 4.2 & 5.07 & 3.9 \\
\hline Neutrophils & $3.0-11.8$ & $\times 10^{3} / \mu \mathrm{l}$ & 2.7 & 1.9 & 1.09 & 1.4 \\
\hline Lymphocytes & $1.0-4.8$ & $\times 10^{3} / \mu \mathrm{l}$ & 1.4 & 2 & 2.68 & 2.2 \\
\hline Monocytes & $0.2-1.4$ & $\times 10^{3} / \mu \mathrm{l}$ & - & 0.2 & 1 & 0.2 \\
\hline Eosinophils & 0.1-1.3 & $\times 10^{3} / \mu \mathrm{l}$ & - & 0.1 & 0.08 & 0.1 \\
\hline $\mathrm{RBC}$ & $5.50-8.50$ & $\times 10^{6} / \mu \mathrm{l}$ & 4.41 & 3.59 & 3.58 & 3.83 \\
\hline $\mathrm{Hgb}$ & $12.0-18.0$ & $\mathrm{~g} / \mathrm{dl}$ & 11.1 & 9.2 & 8.7 & 9.7 \\
\hline Hct & $37.0-55.0$ & $\%$ & 29.9 & 24.2 & 26 & 26.1 \\
\hline MCV & $60.0-74.0$ & $f L$ & 67.8 & 67.4 & 72.8 & 68.1 \\
\hline $\mathrm{MCH}$ & $19.5-24.5$ & $\mathrm{Pg}$ & 25.2 & 25.6 & 24.3 & 25.3 \\
\hline $\mathrm{MCHC}$ & $31.0-36.0$ & $\mathrm{~g} / \mathrm{dl}$ & 37.1 & 38 & 33.4 & 37.2 \\
\hline RDW & $11.0-15.5$ & $\%$ & 13.3 & 12.6 & 11.6 & 13.4 \\
\hline PLT & $200-500$ & $\times 10^{3} / \mu \mathrm{l}$ & 148 & 147 & 121 & 190 \\
\hline MPV & $5.0-15.0$ & $f \mathrm{~L}$ & 6.1 & 6.7 & 14 & 6.6 \\
\hline
\end{tabular}

Table 2. Results of serum chemistry in the present case

\begin{tabular}{lccc}
\hline Analyte & Normal Range & Units & Day 1 \\
\hline Total protein & $5.0-7.2$ & $\mathrm{~g} / \mathrm{dl}$ & 7.3 \\
Albumin & $2.6-4.0$ & $\mathrm{~g} / \mathrm{dl}$ & 2.8 \\
Globulin & $2.0-5.0$ & $\mathrm{~g} / \mathrm{dl}$ & 4.5 \\
ALT & $17-78$ & $\mathrm{U} / \mathrm{L}$ & 34 \\
AST & $17-44$ & $\mathrm{U} / \mathrm{L}$ & 27 \\
ALP & $47-254$ & $\mathrm{U} / \mathrm{L}$ & 537 \\
GGT & $5-14$ & $\mathrm{U} / \mathrm{L}$ & 6 \\
BUN & $9.2-29.2$ & $\mathrm{mg} / \mathrm{dl}$ & 12.3 \\
Creatinine & $0.4-1.4$ & $\mathrm{mg} / \mathrm{dl}$ & 0.2 \\
Glucose & $75-128$ & $\mathrm{mg} / \mathrm{dl}$ & 64 \\
Amylase & $200-1,400$ & $\mathrm{U} / \mathrm{L}$ & 921 \\
Lipase & $10-160$ & $\mathrm{U} / \mathrm{L}$ & 27 \\
Sodium & $141-152$ & $\mathrm{mmol} / \mathrm{L}$ & 140 \\
Potassium & $3.8-5.0$ & $\mathrm{mmol} / \mathrm{L}$ & 3.8 \\
Chloride & $102-117$ & $\mathrm{mmol} / \mathrm{L}$ & 101 \\
\hline
\end{tabular}

\section{CASE RECORD}

In August 2015, a 2-year-old intact male Maltese dog weighing $2.5 \mathrm{~kg}$ presented to the Kwangin Animal Medical Center (Gwangjin-gu, Seoul, Korea) with signs of anorexia and depression. Mild dehydration, pale mucous membranes, and hyperthermia $\left(39.8^{\circ} \mathrm{C}\right)$ were detected in the physical examination, although cardiac auscultation was normal. Table 1 and Table 2 show the results of the clinical and pathological examinations. A complete blood count (CBC) indicated leukopenia

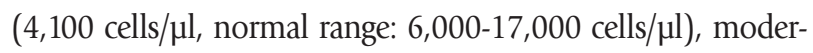
ate anemia (PCV 29.9\%, normal range: 37-55\%), and mild

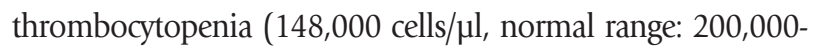
$500,000 \mathrm{cells} / \mu \mathrm{l})$. Serum biochemistry showed mild hypoglycemia, mild hyperproteinemia, increased alkaline phospha-

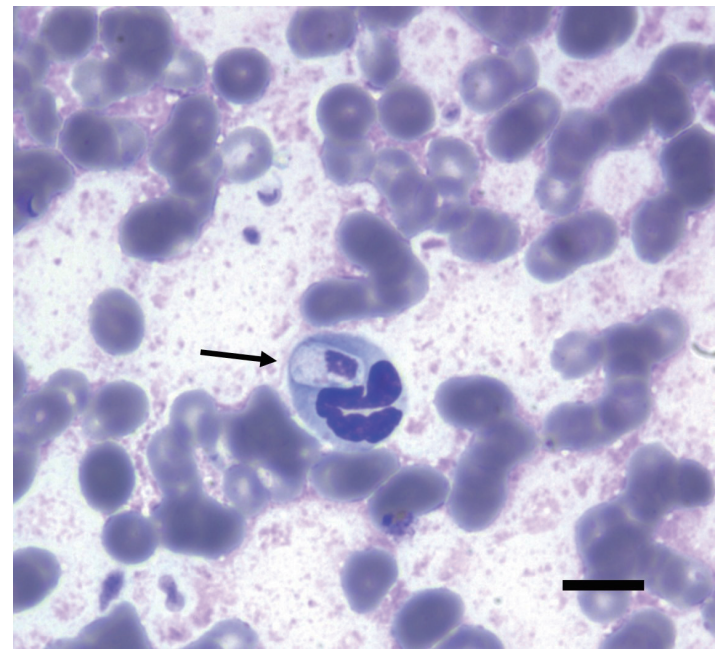

Fig. 1. Diff-Quik-stained peripheral blood smear $(\times 1,000)$ on the first day of hospitalization, showing an ellipsoidal-shaped structure within a neutrophil, indicative of an Hepatozoon canis gamont (arrow). Bar $=10 \mu \mathrm{m}$.

tase, and decreased serum creatinine, sodium, and chloride concentrations.

The serologic tests for canine parvovirus (CPV) and canine distemper virus (CDV) using commercial diagnostic kits (CPV Antigen Test Kit and CDV Antigen Test Kit, Bionote, Hwaseong, Korea) were negative. The results of urinalysis were nonspecific, but the specific gravity was greater than 1.050, suggesting dehydration. Plain radiography and ultrasonography findings were unremarkable. A blood smear examination with DiffQuik staining indicated large intracellular ellipsoidal-shaped structures within a small number of neutrophils (Fig. 1). These structures were morphologically consistent with $H$. canis gamonts. An EDTA whole blood sample was submitted to IDEXX 
Reference Laboratories for real-time PCR analysis (Canine Anemia RealPCR ${ }^{\text {TM }}$ Panel, IDEXX Laboratories, Westbrook, Maine, USA).

While waiting for the real-time PCR results, the symptoms were managed by fluid therapy, antibiotics (cimetidine, metoclopramide, enrofloxacin, and metacam), and regular measurements of body temperature. The symptoms subsided slightly, and the body temperature decreased gradually to $38.1^{\circ} \mathrm{C}$. On day 3 after presentation, the pancytopenia was not resolved, but the clinical signs were less severe and the body temperature returned to the normal range. Additional oral doxycycline (10 mg/kg, p.o., q $24 \mathrm{hr}$ ) was prescribed and the dog was discharged from the hospital. Soon after this, the realtime PCR results indicated the DNA of $H$. canis. There were no signs of recurrence at 5 months after the initial presentation.

\section{DISCUSSION}

H. canis infection was first reported in dogs from India in 1905 [14], and many studies since then have reported on the epidemiology, transmission, pathogenesis, and diagnostic methods of $H$. canis infection $[3,5,10,15]$. In Korea, there have been a few reports on hepatozoonosis. A molecular survey of infections in 184 dogs in the province of Jeju-do in 2008 found that 16 dogs (8.7\%) were infected with H. canis, $14 \operatorname{dogs}(7.6 \%)$ were infected with Babesia gibsoni, and 6 dogs (3.3\%) were infected with both [8], and a leopard cat, Prionailurus bengalensis, in Korea was reported to be infected with H. felis in 2010 [9]. Although the molecular epidemiologic survey confirmed $H$. canis infection in Korean dogs, to our knowledge this is the first report of a dog diagnosed with $H$. canis infection in Korea.

There is a close relationship between the distribution of $H$. canis and its acarine definitive hosts. The brown dog tick, Rhipicephalus sanguineus, is the most important vector in the life cycle of $H$. canis [3], with a study showing experimental transmission of $H$. canis using $R$. sanguineus [16]. This tick species has a nearly worldwide distribution, and is more common in warmer climates [17]. However, studies of tick populations found that R. sanguineus was not present in Korea. For example, an analysis of 3,135 ixodid ticks collected from vegetation and small mammals (wild rodents and insectivores) showed that 2,071 could be identified as Haemaphysalis longicornis, 115 as Haemaphysalis flava, 9 as Ixodes turdus, 3 as Ixodes persulcatus, 20 as Ixodes nipponensis, and 287 as other Ixodes species [18]. Another study of 918 ixodid ticks found that the most com- mon was H. longicornis (54.4\%), followed by other species of the genera Haemaphysalis and Ixodes [19]. An assay of 565 ixodid ticks collected from domestic livestock (cows) also found that the most common tick was H. longicornis (87.4\%), with other ticks including Boophilus microplus, I. persulcatus, R. sanguineus, Argas vespertilionis, and an unidentified species [20].

Similar results were observed in a study of 220 ticks collected from 14 of 58 dogs infected with H. canis in Japan [21]. These ticks were members of the genera Haemaphysalis and Ixodes, but none was found to be R. sanguineus. Histopathologic examination detected oocysts is similar to those of $H$. canis in the haemocoele of $H$. longicornis and $H$. flava, suggesting that $H$. longicornis and $H$. flava may be potential vectors of $H$. canis infection. Although the actual vector is unknown in the present case, this dog was likely infected by a Haemaphysalis species because these are relatively common in Korea.

There is an association between the level of parasitemia and the severity of clinical signs, however most dogs infected with H. canis are asymptomatic or only exhibit mild clinical signs. A case-control study of dogs with $H$. canis infections reported the high parasitemia group was more anemic and neutrophilic than the low parasitemia group and that the high parasitemia group had severe systemic clinical signs including lethargy, fever, weight loss, anorexia, and pale mucous membranes [22]. The dog in the present case had a very low parasite load (less than $1 \%$ ), so there were only mild clinical signs, and it is possible that the clinical signs improved only due to the administration of symptomatic therapy. It was peculiar that pancytopenia was present in the $\mathrm{CBC}$ results. Anemia is the most common blood abnormality in $\mathrm{H}$. canis infections, although a low platelet count occasionally occurs in dogs [10]. The leukocyte count is commonly within the reference interval when the parasitemia is low, but is increased when the parasitemia is high [1]. However, the dog in the present case had leukopenia. Previous studies reported that parasitized neutrophils have reduced myeloperoxidase activity [23] and deficient oxidative bactericidal capacity [24]. Therefore, the leukopenia in the present case might be attributed to a concomitant underlying inflammation.

To date, there has been only 1 report of Hepatozoon infection in a person. This patient presented with anemia and icterus, and histopathologic examinations showed gamonts of Hepatozoon in peripheral blood leukocytes. However, there were no parasites in the liver or bone marrow of this patient. Although the importance of Hepatozoon spp. in zoonotic diseases and 
public health has not been determined, the likelihood of dogto-human transmission is apparently low because Hepatozoon infection occurs following ingestion of an infected tick. However, caution should be exercised when removing ticks from dogs or when handling infected dogs [1].

The present report is the first molecular and biochemical diagnosis of $H$. canis infection in a dog from Korea. H. canis infection should be considered in the differential diagnosis of dogs with fever or anemia.

\section{ACKNOWLEDGMENT}

This work was supported by research funds of Chonbuk National University in 2016.

\section{CONFLICT OF INTEREST}

All authors declare no conflict of interest.

\section{REFERENCES}

1. Greene CE. Infectious Diseases of The Dog and Cat. 4th ed. Missouri, USA. Elsevier Saunders. 2012, pp. 750-757.

2. Baneth G, Mathew JS, Shkap V, Macintire DK, Barta JR, Ewing SA. Canine hepatozoonosis: two disease syndromes caused by separate Hepatozoon spp. Trends Parasitol 2003; 19: 27-31.

3. Baneth G, Samish M, Alekseev E, Aroch I, Shkap V. Transmission of Hepatozoon canis to dogs by naturally-fed or percutaneouslyinjected Rhipicephalus sanguineus ticks. J Parasitol 2001; 87: 606611.

4. Smith TG. The genus Hepatozoon (Apicomplexa: Adeleina). J Parasitol 1996; 82: 565-585.

5. Baneth G, Samish M, Shkap V. Life cycle of Hepatozoon canis (Apicomplexa: Adeleorina: Hepatozoidae) in the tick Rhipicephalus sanguineus and domestic dog (Canis familiaris). J Parasitol 2007; 93: 283-299.

6. Vincent-Johnson NA, Macintire DK, Lindsay DS, Lenz SD, Baneth G, Shkap V, Blagburn BL. A new Hepatozoon species from dogs: description of the causative agent of canine hepatozoonosis in North America. J Parasitol 1997; 83: 1165-1172.

7. Baneth G, Barta JR, Shkap V, Martin DS, Macintire DK, VincentJohnson N. Genetic and antigenic evidence supports the separation of Hepatozoon canis and Hepatozoon americanum at the species level. J Clin Microbiol 2000; 38: 1298-1301.

8. Kwak DH, Kim YG, Ji HJ, Lee KK, Yun YM. Molecular survey of Babesia gibsoni and Hepatozoon canis infection in dogs from Jeju island. J Vet Clin 2008; 10: 154 (in Korean).

9. Kubo M, Jeong A, Kim SI, Kim YJ, Lee H, Kimura J, Agatsuma T,
Sakai H, Yanai T. The first report of Hepatozoon species infection in leopard cats (Prionailurus bengalensis) in Korea. J Parasitol 2010; 96: 437-439.

10. Baneth G, Weigler B. Retrospective case-control study of Hepatozoonosis in dogs in Israel. J Vet Intern Med 1997; 11: 365-370.

11. Otranto D Dantas-Torres F, Weigl S, Latrofa MS, Stanneck D, Decaprariis D, Capelli G, Baneth G. Diagnosis of Hepatozoon canis in young dogs by cytology and PCR. Parasit Vectors 2011; 4: 55.

12. Li Y, Wang C, Allen KE, Little SE, Ahluwalia SK, Gao D, Macintire DK, Blagburn BL, Kaltenboeck B. Diagnosis of canine Hepatozoon spp. infection by quantitative PCR. Vet Parasitol 2008; 157: 50-58.

13. Gonen L, Strauss-Ayali D, Shkap V, Vincent-Johnson N, Macintire DK, Baneth G. An enzyme-linked immunosorbent assay for antibodies to Hepatozoon canis. Vet Parasitol 2004; 122: 131-139.

14. James SP. On a parasite found in the white corpuscles of the blood of dogs. Sci Mem Offrs Med Sanit Deps India 1905; 14: 1-12.

15. Craig TM, Smallwood JE, Knauer KW, McGrath JP. Hepatozoon canis infection in dogs: clinical, radiographic, and hematologic findings. J Am Vet Med Assoc 1978; 173: 967-972.

16. Nordgren RM, Craig TM. Experimental transmission of the Texas strain of Hepatozoon canis. Vet Parasitol 1984; 16: 207-214.

17. Dantas-Torres F. The brown dog tick, Rhipicephalus sanguineus (Latreille, 1806) (Acari: Ixodidae): from taxonomy to control. Vet Parasitol 2008; 152: 173-185.

18. Kim CM, Yi YH, Yu DH, Lee MJ, Cho MR, Desai AR, Shringi S, Klein TA, Kim HC, Song JW, Baek LJ, Chong ST, O'guinn ML, Lee JS, Lee IY, Park JH, Foley J, Chae JS. Tick-borne rickettsial pathogens in ticks and small mammals in Korea. Appl Environ Microbiol 2006; 72: 5766-5776.

19. Kim HC, Han SH, Chong ST, Klein TA, Choi CY, Nam HY, Chae HY, Lee H, Ko S, Kang JG, Chae JS. Ticks collected from selected mammalian hosts surveyed in the Republic of Korea during 2008-2009. Korean J Parasitol 2011; 49: 331-335.

20. Kang YB. Studies on tick eradication in Korea (1982-1984). Special project for animal health. Ann Rep Inst Vet Res, Rural Develop Admin 1984: 269-305.

21. Murata T, Inoue M, Taura Y, Nakama S, Abe H, Fujisaki K. Detection of Hepatozoon canis oocyst from ticks collected from the infected dogs. JVet Med Sci 1995; 57: 111-112.

22. Karagenc TI, Pasa S, Kirli G, Hosgor M, Bilgic HB, Ozon YH, Atasoy A, Eren H. A parasitological, molecular and serological survey of Hepatozoon canis infection in dogs around the Aegean coast of Turkey. Vet Parasitol 2006; 135: 113-119.

23. Ibrahim ND, Rahamathulla PM, Njoku CO. Neutrophil myeloperoxidase deficiency associated with canine hepatozoonosis. Int J Parasitol 1989; 19: 915-918.

24. Murata T, Tagami R, Inoue M, Uzuka Y, Taura Y, Nakama S. Investigation of nitroblue tetrazolium reduction of neutrophils in the dog infected with Hepatozoon canis. Jikken Dobutsu 1994; 43: 101-103 (in Japanese). 